\title{
Cross-cultural adaptation of the Bonn Palliative Care Knowledge Test: an instrument to assess knowledge and self-efficacy
}

\author{
Adaptaçáo transcultural do Bonn Palliative Care Knowledge Test: um instrumento para \\ avaliar conhecimentos e autoeficácia \\ Adaptación transcultural del Bonn Palliative Care Knowledge Test: un instrumento para \\ evaluar conocimientos y autoeficacia
}

Jéssica Sponton Moura Minosso*; Maria Manuela Ferreira Pereira da Silva Martins**; Maria Amélia de Campos Oliveira***

\begin{abstract}
Background: Palliative care (PC) improves the quality of life of people with advanced disease and optimizes the use of health-related resources. However, health professionals' lack of knowledge about PC may become a barrier to its availability. Nursing requires instruments that can identify possible gaps in this set of knowledge, both in PC practice and teaching.

Objectives: To promote the cross-cultural adaptation of the Bonner Palliativwissenstest (BPW) to measure undergraduate students and nurses' knowledge and self-efficacy beliefs about PC in Portugal.

Methodology: A 6-step methodological study was conducted with 60 participants in the pretest stage.

Results: The procedures promoted semantic, idiomatic, cultural, and conceptual equivalences. The pretest confirmed the understanding and acceptability of the elaborated version. The mean score was similar to that found in the original study. Conclusion: The Portuguese version of the BPW showed an adequate equivalence to the original instrument.
\end{abstract}

Keywords: palliative care; clinical competence; professional practice; hospice and palliative care nursing; education, nursing

\section{Resumo}

Enquadramento: Os cuidados paliativos (CP) aumentam a qualidade de vida das pessoas com doença avançada e otimizam o uso dos recursos em saúde. Entretanto, a insuficiência de conhecimentos dos profissionais de saúde sobre CP pode constituir-se numa barreira para a sua disponibilização. A Enfermagem carece de instrumentos que identifiquem possíveis lacunas neste corpo de conhecimentos, tanto na prática como no ensino de CP.

Objetivos: Promover a adaptação transcultural Bonner Palliativwissenstest (BPW) para a avaliação de conhecimentos e crenças de autoeficácia em CP de licenciandos e enfermeiros em Portugal.

Metodologia: Realizou-se um estudo metodológico, composto por 6 etapas, com 60 participantes na fase de pré-teste. Resultados: Os procedimentos adotados promoveram a consecução das equivalências semântica, idiomática, cultural e conceitual. O pré-teste confirmou a compreensão e a aceitabilidade da versão elaborada. A média de acertos foi similar à encontrada no estudo original.

Conclusão: A versão portuguesa do BPW apresentou equivalências adequadas ao instrumento original.

Palavras-chave: cuidados paliativos; competência clínica; prática profissional; enfermagem de cuidados paliativos na terminalidade da vida; educação em enfermagem

*MSc., RN, School of Nursing, University of São Paulo, 05403-000, São Paulo, Brazil [jessica. minosso@usp.br]. Contribution to the article: literature search, data collection, statistical treatment, data analysis and discussion, article writing.

Address for correspondence: Rua Parque da República, 148 casa 8, 4430-999, Vila Nova de Gaia, Portugal.

**Ph.D., Coordinating Professor, Nursing School of Porto, 4200-072, Porto, Portugal [mmartins@esenf.pt]. Contribution to the article: data collection and analysis, article writing.

*** Ph.D., Full Professor, School of Nursing, University of São Paulo, 05403-000, São Paulo, Brazil [macampos@usp.br].Contribution to the article: data analysis and discussion, article writing.

\section{Resumen}

Marco contextual: Los cuidados paliativos (CP) aumentan la calidad de vida de las personas con enfermedad avanzada y optimizan el uso de los recursos en la salud. Entretanto, la falta de conocimiento de los profesionales de la salud sobre CP puede significar una barrera para ponerlos a disposición. La enfermería carece de instrumentos que identifiquen posibles lagunas en este cuerpo de conocimientos, tanto en la práctica como en la enseñanza de CP.

Objetivos: Promover la adaptación transcultural del Bonner Palliativwissenstest (BPW) para evaluar conocimientos y creencias de autoeficacia en CP de graduandos y enfermeros en Portugal.

Metodología: Se realizó un estudio metodológico, compuesto por 6 etapas, con 60 participantes en la fase de pretest.

Resultados: Los procedimientos adoptados promovieron la consecución de las equivalencias semántica, idiomática, cultural y conceptual. El pretest confirmó la comprensión y la aceptabilidad de la versión elaborada. La media de aciertos fue similar a la encontrada en el estudio original.

Conclusión: La versión portuguesa del BPW presentó equivalencias adecuadas al instrumento original.

Palabras clave: cuidados paliativos; competencia clínica; práctica profesional; enfermería de cuidados paliativos al final de la vida; educación en enfermería

Received for publication: 15.11 .16

Accepted for publication: 17.01.17 


\section{Introduction}

The increase in life expectancy is one of the greatest achievements of mankind and, simultaneously, a major threat to the economic and social stability in the next century. In general, health systems are ill-prepared to provide appropriate care to people with chronic disease and associated complications (Prince et al., 2015).

It is estimated that approximately $75 \%$ of people will die in developed countries as a result of the progression of chronic diseases. For this reason, the World Health Organization (WHO) recommends the inclusion of strategies to cope with chronic conditions in health systems (Tripodoro et al., 2016; World Health Organization [WHO], 2015).

Palliative care (PC) is an effective strategy in cases of advanced disease, by relieving suffering, improving quality of life, and optimizing the use of health-related resources (Seow et al., 2014). The importance of PC has clearly expanded worldwide as an essential response to physical symptoms and unattended psychosocial issues that accompany the chronically ill patient until the end of life (Burlá \& Py, 2014).

One of the major barriers to the provision of this type of care is the inadequate tr aining of health professionals, who have little knowledge about PC. The lack of incorporation of PC-related contents into the curricula of undergraduate degrees in the health area is a well-known fact (Al Qadire, 2014; WHO, 2015). The gaps identified in nursing degrees include topics such as management of pain and other symptoms, use of opiates and other specific medications, and management of side effects (Prem et al., 2012).

In fact, there is a set of knowledge inherent to the proper treatment of people in PC that defies even the parameters established in evidence-based practice. Heterogeneous populations, the specific goals of treatments not aimed at the cure, the specific trajectory of chronic diseases and their outcomes, and the holistic nature of PC make randomized clinical trials often inapplicable or inappropriate, both for practical and ethical reasons (Visser, Hadley, \& Wee, 2015).

The implementation of $\mathrm{PC}$ is complex given the characteristics of people with advanced disease, who usually have multiple symptoms, as well as the need for interventions from various specialties and support aimed at caregivers and families. The development of professionals' skills, knowledge, and attitudes has been identified as a facilitator of this process (van Riet Paap et al., 2014). In this context, self-efficacy also assumes an important role, as it is one of the beliefs that determine individuals' behavior since it is at the root of actions performed to reach a certain goal (Laochite, Costa Filho, Matos, \& Sachimbombo, 2016).

Therefore, taking into account that there is no instrument to assess nurses' skills and training for PC delivery, this study aimed at performing the cross-cultural adaptation of the Bonn Palliative Care Knowledge Test to be applied to undergraduate students and nurses in Portugal.

\section{Background}

The need to assess students and nurses' knowledge about PC has given rise to some instruments. The Palliative Care Quiz for Nursing (PCQN) is one of the most commonly used instruments. It is a reliable and easy-to-apply tool; however, it was developed in the late 1990s and does not include the current recommendations of the WHO (Ross, McDonald's, \& McGuinness, 1996). In 2009, Japanese researchers developed the Palliative Care Knowledge Test (PCKT; Nakazawa et al., 2009), and its validity has been proven in a large sample of nurses. However, this instrument does not assess the psychosocial issues related to the provision of $\mathrm{PC}$ to patients.

In 2011, in Germany, a group of researchers developed a scale to measure health professionals' knowledge about PC and their self-efficacy beliefs - the Bonn Palliative Care Knowledge Test. This instrument, which is the one selected for this study, was originally developed for use in nursing homes and incorporates the recent changes in the WHO guidelines regarding PC (Pfister et al., 2011). In the process of adaptation of the Bonn Palliative Care Knowledge Test (Bonner Palliativwissenstest - BPW) into Portuguese, we used the English version of the instrument - developed 
by the authors themselves - and included only the questions validated in the original study. It includes 23 items that analyze the PC-related knowledge, covering topics such as pain and symptom management, general knowledge about PC, and attitudes toward death and dying. In addition, it includes 15 questions that assess self-efficacy in PC delivery. The Likert-type scale was composed of the following response options: "correct", "rather correct", "barely correct", and "incorrect". Its validity and reliability have been confirmed, with Cronbach's alpha values of 0.71 for the items on knowledge and 0.86 for the items on self-efficacy (Pfister et al., 2011).

The need for the adaptation of an instrument designed base on a different linguistic and cultural context is widely recognized. The process goes far beyond the mere translation and it usually involves several steps aimed at eliminating biases in the studies and ensuring the reliability of results (Gjersing, Caplehorn, \& Clausen, 2010).

\section{Research question}

Given the need to assess knowledge about PC and its provision, this study was developed to answer the following question: Is the Portuguese version of the BPW equivalent to the original instrument, thus being able to assess students and nurses' knowledge and self-efficacy beliefs in Portugal?

\section{Methodology}

This was a methodological study, based on a theoretical framework for cross-cultural adaptations (Beaton, Bombardier, Guillemin, \& Ferraz, 2000), with the following stages: translation, synthesis, translation, expert committee review, pretesting, and submission of the translation to the researchers who developed the instrument. We used the English version of the BPW (Pfister et al., 2013), which was designed by the authors of the original instrument after consulting experts in instrument adaptation. The authors of the BPW authorized and followed-up the cross-cultural adaptation process.

\section{Translation}

Two independent Portuguese native translators produced two versions of the original instrument (identified as T1 and T2). Translators were asked to produce reports on the translation, with comments on the easiest and most difficult aspects and rationale for their choices. Translators had no contact with each other, nor were they were given access to each other's version.

\section{Synthesis of translations}

Using the documents produced by the translators and the original version of the instrument, the researchers developed a synthesis of the translations submitted, identified as T-12. The process was carefully documented in a report with comments on the items that generated disagreements and how they were resolved.

\section{Back-translation}

Based on the synthesis of the translations (T12), two independent English native translators translated the instrument back to the original language, producing the versions identified as RT1 and RT2. None of them had any knowledge of the concepts explored in the BPW, the original instrument, or the versions previously produced.

\section{Expert committee}

The expert committee was composed of seven bilingual professionals (English/Portuguese): generalist nurses, nurses specialized in PC, and teachers of undergraduate and post-graduate Nursing degrees. The versions of the instrument (T1, T2, T-12, RT1, and RT2) and the reports were made available to the members of the committee, who examined the documents and drafted the pre-final version of the BPW in European Portuguese, with the purpose of safeguarding the semantic, idiomatic, cultural, and conceptual equivalence of the original instrument.

\section{Pretesting}

The adopted theoretical framework (Beaton et al., 2000) recommends that the instrument should be tested with 30 to 40 people from the target population. Considering the study objectives, the pretest was performed with 
30 nurses and 30 nursing undergraduate students who were selected through a convenience sampling method. All the guidelines recommended by the National Ethics Council for the Life Sciences in Portugal were followed. The Ethics Committee of the Nursing School of Porto authorized the participation of students in the pretest. The study participants signed an informed consent form.

The Portuguese version of the BPW and the documents produced in the adaptation process were sent to the authors of the original instrument.

\section{Results}

In the translation stage, no significant semantic differences were found between both versions. One of the translators chose to use medical terminology more often due to the target audience of the instrument. As an example, we can mention the change from the expression boca seca (dry mouth) to xerostomia (xerostomy).

When performing the synthesis of the translations, the researchers agreed with the translation of most items, and made only minor changes such as sentence structure, use of simpler terms, and adequacy to the standard of health-related instruments.

An important change was the replacement of the term residentes (residents) for pacientes (patients), so as to extend the range of application of the instrument beyond nursing homes (Table 1). The authors of the instrument made no comments or observations regarding this change.

Table 1

Main differences between the original version and the synthesis of the Portuguese translations of the BPW. Porto, 2015

\begin{tabular}{ll}
\hline BPW original & Synthesis of translations \\
\hline $\begin{array}{l}\text { Management with an opioid patch is adequate for } \\
\text { residents in the final phase of life suffering from pain. }\end{array}$ & $\begin{array}{l}\text { A gestão da dor com adesivo transdérmico opioide é ade- } \\
\text { quada para pacientes em fase terminal que sentem dor. }\end{array}$ \\
\hline $\begin{array}{l}\text { Residents with life threatening illness should always } \\
\text { be told the truth to allow them to prepare for death. }\end{array}$ & $\begin{array}{l}\text { Os pacientes com doenças que ameaçam a continuidade } \\
\text { da vida devem ser sempre informados da verdade, para que } \\
\text { possam preparar-se para a morte. }\end{array}$ \\
\hline $\begin{array}{l}\text { Corridor neighbors should not be informed about } \\
\text { the death of a resident to avoid unrest. }\end{array}$ & $\begin{array}{l}\text { Os pacientes dos quartos adjacentes não devem ser in- } \\
\text { formados sobre a morte de um doente, para evitar in- } \\
\text { quietaçóes. }\end{array}$ \\
\hline $\begin{array}{l}\text { Visible rituals and farewell ceremonies should be } \\
\text { avoided when a resident has died to prevent unrest. }\end{array}$ & $\begin{array}{l}\text { Quando morre um paciente, os rituais visíveis e as ce- } \\
\text { rimónias de despedida devem ser evitados para evitar } \\
\text { perturbaçóes }\end{array}$ \\
\hline $\begin{array}{l}\text { The caregiver's own feelings (for example disgust) can } \\
\text { be shown in the care of residents. }\end{array}$ & $\begin{array}{l}\text { Os sentimentos do prestador de cuidados (por exemplo, } \\
\text { repulsa) podem transparecer durante a prestaçáo de cui- } \\
\text { dados aos pacientes. }\end{array}$ \\
\hline $\begin{array}{l}\text { Identifying the complex needs of a dying resident } \\
\text { and reacting appropriately. }\end{array}$ & $\begin{array}{l}\text { Identificar as complexas necessidades de um paciente em } \\
\text { final de vida e reagir de forma adequada. }\end{array}$ \\
\hline $\begin{array}{l}\text { Performing adequate mouth care for dying residents. } \\
\text { Identifying specific psychological problems of resi- } \\
\text { dents. }\end{array}$ & $\begin{array}{l}\text { Identificar problemas psicológicos específicos dos pacien- } \\
\text { tes. }\end{array}$ \\
\hline
\end{tabular}

After the back-translation stage, no significant differences were found between the versions, which proved to be similar to the original instrument, with the exception of one of the questions (Table 2). 
Table 2

Main differences between the back-translations and the original instrument. Porto, 2015

\begin{tabular}{lll}
\hline RT1 & RT2 & BPW original \\
\hline $\begin{array}{l}\text { Adjuvant therapies (such as physio- } \\
\text { therapy) are important for treating } \\
\text { pain. }\end{array}$ & $\begin{array}{l}\text { Adjuvant treatments (such as physical } \\
\text { therapy) are important to treat pain. }\end{array}$ & $\begin{array}{l}\text { Adjuvant therapies (for example phys- } \\
\text { iotherapy) are important for pain man- } \\
\text { agement. }\end{array}$ \\
\hline $\begin{array}{l}\text { Palliative care involves constant emo- } \\
\text { tional closeness. }\end{array}$ & $\begin{array}{l}\text { Palliative care implies constant emo- } \\
\text { tional closeness. }\end{array}$ & $\begin{array}{l}\text { Palliative care calls for constant emo- } \\
\text { tional closeness. }\end{array}$ \\
\hline $\begin{array}{l}\text { Patients with life-threatening illness- } \\
\text { es should always be told the truth, } \\
\text { so they can prepare themselves for } \\
\text { death. }\end{array}$ & $\begin{array}{l}\text { Patients with illnesses that threaten } \\
\text { truthes so they can prepare themselves } \\
\text { for death. }\end{array}$ & $\begin{array}{l}\text { Residents with life threatening illness } \\
\text { should always be told the truth to allow } \\
\text { them to prepare for death. }\end{array}$ \\
$\begin{array}{l}\text { The treatment's medical aspects al- } \\
\text { ways take precedence in palliative } \\
\text { care. }\end{array}$ & $\begin{array}{l}\text { The treatment's medical aspects always } \\
\text { take priority in palliative care. }\end{array}$ & $\begin{array}{l}\text { Medical aspects of treatment always } \\
\text { have priority in palliative care. }\end{array}$ \\
\hline $\begin{array}{l}\text { Establish relationships of empathy } \\
\text { with the patient and his/her family } \\
\text { and related needs. }\end{array}$ & $\begin{array}{l}\text { Establish empathic relationships with } \\
\text { the patient and his/her family and as- } \\
\text { sociated needs. }\end{array}$ & $\begin{array}{l}\text { Empathizing with different life situa- } \\
\text { tions, family constellations, and asso- } \\
\text { ciated needs of patients and reacting } \\
\text { appropriately. }\end{array}$ \\
\hline
\end{tabular}

In the expert committee review, the experts analyzed each item and proposed several changes. The decisions were made by consensus, seeking to obtain the various types of equivalence recommended by the adopted theoretical framework (Beaton et al., 2000), thus consolidating the pre-final version. Similarly to what happened in the synthesis stage, the committee experts chose to use the term pessoa (person) or paciente (patient) instead of the term residente (resident).

The resulting version was administered to a sample of nurses and nursing students. Each group was composed of 30 participants. A question- naire was also applied for the sociodemographic characterization of the samples.

Most of the participants were female (88.33\%), with a mean age of 26.8 years $(S D=8.454)$. They reported having already experienced the process of death/dying of relatives $(86.7 \%)$, having no specific training in PC $(90 \%)$, feeling unable to provide PC (76.7\%), and assigning importance to the inclusion of PC-related contents into undergraduate curricula (100\%). The main differences found between students and professionals were related to the experience with people in PC and the ability to provide PC. Table 3 details the characteristics of the sample.

Table 3

Sociodemographic characteristics of the samples. Porto, 2015

\begin{tabular}{lcc}
\hline Characteristics & $\begin{array}{c}\text { Students } \\
n(\%)\end{array}$ & $\begin{array}{c}\text { Professionals } \\
n(\%)\end{array}$ \\
\hline Gender & & $24(80)$ \\
Female & $29(96.7)$ & $6(20)$ \\
Male & $1(3.3)$ & \\
Age (in years) & & 32.67 \\
Mean & 20.72 & 29.50 \\
Median & 20.00 & 8.239 \\
Standard deviation & 1.623 & 23 \\
Minimum & 20 & 56
\end{tabular}


Marital status

Single

$28(93.3)$

2(6.7)

$14(46.7)$

Married

Co-habiting

Have you ever experienced the dying process/death of close relatives?

Yes

No

Do you have any experience with PC patients?

Yes

No

Do you have specific training in PC?

Yes

$30(100)$

No

Do you think that PC is a specific area of knowledge within Nursing? Yes

No

Do not know

Did not answer

Do you think you are capable of providing PC to patients?

Yes

No

Did not answer

Do you think that it is important to include PC-related contents in undergraduate curricula?

Yes

30(100)

$30(100)$

No

Would you like to work in PC units?

Yes

None of the respondents expressed difficulties in completing the instrument. Comments were made about the large number of items in the instrument and the time re-

Table 4

Portuguese version of the BPW. Porto, 2015 quired to answer them. The instrument was completed on average in 10 minutes. Table 4 shows the Portuguese final version of the BPW .

\begin{tabular}{lcc}
\hline BPW & Correto \\
(Bonn Palliative Care Knowledge Test) & $\begin{array}{c}\text { Razolmente } \\
\text { Correto }\end{array}$ & $\begin{array}{c}\text { Pouco } \\
\text { Correto }\end{array}$
\end{tabular} Incorreto

Secção 1 - Conhecimentos

1. Os CP nunca devem ser combinados com tratamentos curativos

2. Os fármacos anti-inflamatórios não esteroides não devem ser utilizados em caso de administraçáo regular de opioides

3. A administração de fluidos por via subcutânea é necessária para o alívio da xerostomia (boca seca) na pessoa em fim de vida

4. A gestão da dor com opioide transdérmico é adequada para a pessoa em fim de vida 
5. As terapias não farmacológicas (por exemplo, fisioterapia) são importantes na gestão da dor

6. Para os familiares é sempre importante permanecer junto à pessoa nas últimas horas de vida até que a morte ocorra

7. A obstipação deve ser aceite como um efeito secundário, porque a gestão da dor é mais importante

8. Os $\mathrm{CP}$ requerem uma proximidade emocional constante

9. Com o avanço da idade, as pessoas aprenderam a lidar com a dor de forma independente, em resultado de várias experiências

10. A filosofia dos $\mathrm{CP}$ preconiza que não sejam realizadas quaisquer intervençôes destinadas a prolongar a vida

11. O limiar da dor é diminuído pela ansiedade ou fadiga

12. As pessoas com doenças que ameaçam a vida devem ser sempre informadas da verdade, para que possam preparar o seu processo de morrer

13. Os membros da equipa náo têm de ser crentes para prestar cuidados espirituais à pessoa em fim de vida

14. A pessoa que recebe CP deve aceitar a morte

15. As competências de comunicação podem ser aprendidas

16. Os outros pacientes não devem ser informados sobre a morte da pessoa para evitar inquietaçóes

17. O tratamento médico tem sempre prioridade nos $\mathrm{CP}$

18. Quando morre uma pessoa, os rituais visíveis e as cerimónias de despedida devem ser evitadas para não causar inquietaçóes

19. O uso de antidepressivos na gestão da dor não é adequado

20. Os analgésicos adjuvantes não são necessários durante o tratamento com opioides

21. A fase final refere-se aos últimos 3 dias de vida

22. Os sentimentos do cuidador (por exemplo, repulsa) podem transparecer durante o cuidado à pessoa

23. As necessidades fisiológicas (por exemplo, a sexualidade) são importantes mesmo no processo de morrer

Secção 2 - Avaliação da autoeficácia

Penso que sou capaz de...

$\begin{array}{cccc} & \text { Razoavel- } & \text { Pouco } & \\ \text { Correto } & \text { mente } & \text { Correto } & \\ & \text { Correto } & \end{array}$

1. Obter dados objetivos que descrevam a intensidade da dor da pessoa em CP

2. Aconselhar as pessoas em CP sobre como aliviar as náuseas

3. Informar a pessoa e seus familiares sobre CP prestados pelo serviço de saúde

4. Convencer o médico sobre a necessidade de apoio de CP

5. Identificar e discutir problemas reais no ambiente social da pessoa em CP

6. Organizar o contacto com um serviço de $\mathrm{CP}$ 
7. Comunicar com a pessoa ansiosa e seus familiares em CP de forma a fazê-los sentirem-se seguros

8. Identificar as necessidades complexas da pessoa em fim de vida e intervir de forma adequada

9. Ensinar estratégias de relaxamento a uma pessoa com dor em CP

10. Comunicar com a pessoa em CP que expressa o desejo de antecipar a morte

11. Prestar os cuidados orais adequados à pessoa em fim de vida

12. Informar a pessoa em CP sobre possíveis efeitos secundários dos medicamentos prescritos

13. Identificar problemas psicológicos específicos das pessoas em CP

14. Integrar os aspetos culturais da morte e do morrer nos cuidados a pacientes em fim de vida

15. Criar empatia com a pessoa em CP em diferentes situaçôes de vida, relaçôes familiares e necessidades, e intervir

The results of the assessment of the participants' knowledge and self-efficacy using the BPW are shown in Tables 5 and 6, respectively. According to the authors of the instrument, items 1-4, $6-10,12,14$, and 16-20 should be considered barely correct or incorrect, and the remaining items $(5,11,13,15,21-23)$ correct or rather correct (Pfister et al., 2013). The mean score was only slightly different among the groups of students and professionals who participated in the pretest. The difference was more marked regarding self-efficacy.

\section{Table 5}

Results of the assessment of knowledge of the pretest sample. Porto, 2015

\begin{tabular}{|c|c|c|}
\hline \multirow[b]{2}{*}{ Section 1 - Knowledge } & \multicolumn{2}{|c|}{ Correct answers } \\
\hline & $\begin{array}{l}\text { Students } \\
(\%)\end{array}$ & $\begin{array}{l}\text { Professionals } \\
\qquad(\%)\end{array}$ \\
\hline 1. Os CP nunca devem ser combinados com tratamentos curativos & 63,3 & 70 \\
\hline $\begin{array}{l}\text { 2. Os fármacos anti-inflamatórios não esteroides não devem ser utilizados em } \\
\text { caso de administração regular de opioides }\end{array}$ & 60 & 56,7 \\
\hline $\begin{array}{l}\text { 3. A administração de fluidos por via subcutânea é necessária para o alívio da } \\
\text { xerostomia (boca seca) na pessoa em fim de vida. }\end{array}$ & 50 & 36,7 \\
\hline $\begin{array}{l}\text { 4. A gestấo da dor com opioide transdérmico é adequada para a pessoa em } \\
\text { fim de vida }\end{array}$ & 30 & 50 \\
\hline $\begin{array}{l}\text { 5. As terapias não farmacológicas (por exemplo, fisioterapia) são importantes } \\
\text { na gestấo da dor }\end{array}$ & 80 & 80 \\
\hline $\begin{array}{l}\text { 6. Para os familiares é sempre importante permanecer junto à pessoa nas últi- } \\
\text { mas horas de vida até que a morte ocorra }\end{array}$ & 3,3 & 23,3 \\
\hline $\begin{array}{l}\text { 7. A obstipaçấo deve ser aceite como um efeito secundário, porque a gestão } \\
\text { da dor é mais importante }\end{array}$ & 43,3 & 60 \\
\hline 8. Os CP requerem uma proximidade emocional constante & 20 & 20 \\
\hline $\begin{array}{l}\text { 9. Com o avanço da idade, as pessoas aprenderam a lidar com a dor de forma } \\
\text { independente, em resultado de várias experiências }\end{array}$ & 73,3 & 53,3 \\
\hline $\begin{array}{l}\text { 10. A filosofia dos CP preconiza que não sejam realizadas quaisquer interven- } \\
\text { çóes destinadas a prolongar a vida }\end{array}$ & 26,7 & 33,3 \\
\hline
\end{tabular}


12. As pessoas com doenças que ameaçam a vida devem ser sempre informadas da verdade, para que possam preparar o seu processo de morrer

13. Os membros da equipa não têm de ser crentes para prestar cuidados espirituais à pessoa em fim de vida

14. A pessoa que recebe $\mathrm{CP}$ deve aceitar a morte

15. As competências de comunicação podem ser aprendidas

16. Os outros pacientes não devem ser informados sobre a morte da pessoa para evitar inquietaçóes

17. O tratamento médico tem sempre prioridade nos CP

18. Quando morre uma pessoa, os rituais visíveis e as cerimónias de despedida devem ser evitadas para não causar inquietaçóes

19. O uso de antidepressivos na gestão da dor não é adequado.

20. Os analgésicos adjuvantes não são necessários durante o tratamento com opioides

21. A fase final refere-se aos últimos 3 dias de vida

22. Os sentimentos do cuidador (por exemplo, repulsa) podem transparecer durante o cuidado à pessoa

23. As necessidades fisiológicas (por exemplo, a sexualidade) são importantes mesmo no processo de morrer

Table 6

Assessment of self-efficacy of the pretest sample. Porto, 2015

\begin{tabular}{|c|c|c|}
\hline \multirow[b]{2}{*}{ Secção 2 - Autoeficácia } & \multicolumn{2}{|c|}{ They think they are capable of } \\
\hline & $\begin{array}{c}\text { Students } \\
(\%)\end{array}$ & $\begin{array}{c}\text { Professionals } \\
(\%)\end{array}$ \\
\hline $\begin{array}{l}\text { 1. Obter dados objetivos que descrevam a intensidade da dor da pessoa } \\
\text { em CP }\end{array}$ & 83,3 & 86,67 \\
\hline 2. Aconselhar as pessoas em $\mathrm{CP}$ sobre como aliviar as náuseas & 60 & 90 \\
\hline $\begin{array}{l}\text { 3. Informar a pessoa e seus familiares sobre CP prestados pelo serviço de } \\
\text { saúde }\end{array}$ & 60 & 83,33 \\
\hline 4. Convencer o médico sobre a necessidade de apoio de CP & 63,3 & 83,33 \\
\hline 5. Identificar e discutir problemas reais no ambiente social da pessoa em CP & 46,65 & 83,33 \\
\hline 6. Organizar o contacto com um serviço de CP & 36,66 & 76,67 \\
\hline $\begin{array}{l}\text { 7. Comunicar com a pessoa ansiosa e seus familiares em CP de forma a } \\
\text { fazê-los sentirem-se seguros }\end{array}$ & 40 & 83,33 \\
\hline $\begin{array}{l}\text { 8. Identificar as necessidades complexas da pessoa em fim de vida e intervir } \\
\text { de forma adequada }\end{array}$ & 50 & 76,67 \\
\hline 9. Ensinar estratégias de relaxamento a uma pessoa com dor em CP & 70 & 70 \\
\hline $\begin{array}{l}\text { 10. Comunicar com a pessoa em CP que expressa o desejo de antecipar a } \\
\text { morte }\end{array}$ & 26,67 & 70 \\
\hline 11. Prestar os cuidados orais adequados à pessoa em fim de vida & 76,67 & 90 \\
\hline $\begin{array}{l}\text { 12. Informar a pessoa em CP sobre possíveis efeitos secundários dos medi- } \\
\text { camentos prescritos }\end{array}$ & 76,67 & 90 \\
\hline
\end{tabular}


13. Identificar problemas psicológicos específicos das pessoas em CP

14. Integrar os aspectos culturais da morte e do morrer nos cuidados a pacientes em fim de vida

15. Criar empatia com a pessoa em CP em diferentes situaçóes de vida, rela-

\section{Discussion}

Studies have shown that there is a deficit of PC-related knowledge among health professionals (Prem et al., 2012). This raises the awareness for the need to improve the teaching of $\mathrm{PC}$ in undergraduate degrees.

The BPW can become an important tool to assess professionals and students' level of knowledge, emphasizing specific areas of practice and education, both in health and in education institutions. In addition, it also measures self-efficacy, a concept that has proven important to the extent that it is reflected in individual behavior (Iaochite et al., 2016). The instrument had been developed for the German context, so it had to undergo a cross-cultural adaptation process. This process aims at achieving a semantic, idiomatic, cultural, and conceptual equivalence between versions of measuring instruments in different languages and cultural contexts (Beaton et al., 2000).

One of the most important changes in the adaptation process was the expansion of its use to other institutions and health care settings, rather than being used only in nursing homes.

In the pretesting stage, the demographic data confirmed the results of some studies, such as the inadequate inclusion of PC-related contents in health degrees, despite of the importance assigned to them by students and alumni (Mutto, Cantoni, Rabhansl, \& Villar, 2012).

There was also a high percentage of respondents who considered themselves to be unfit for PC delivery, which is in line with data from other studies (Henderson, Rowe, Watson, \& Hitchen-Holmes, 2016).

The results obtained in the pretest confirmed a level of knowledge (57-62\%) similar to that found by the authors of the instrument and in similar studies (Kassa, Murugan, Zewdu, Hailu, \& Woldeyohannes, 2014; Pfister et al., 2013), which is considered low compared to those obtained by the experts in the validation study (mean score of $77.8 \%$ ). The most dramatic change in self-efficacy between the groups of students $(56.67 \%)$ and professionals $(80.65 \%)$ does not reflect the results obtained in the study by the authors of the instrument (Pfister et al., 2013), which showed a negative correlation between the years of experience and the self-efficacy score. Future studies, with larger samples and more statistical tests, will be conducted to clarify/confirm the data obtained.

\section{Conclusion}

The final version in Portuguese of the Bonn Palliative Care Knowledge Test showed an adequate equivalence to the original instrument, as can be seen in the procedures adopted. The adjustments produced a viable tool to be used in the Portuguese context. Further studies will be developed to obtain evidence on the validity of the Portuguese version of the BPW.

\section{References}

Al Qadire, M. (2014). Knowledge of palliative care: An online survey. Nurse Education Today, 34(5), 714718. doi:10.1016/j.nedt.2013.08.019

Beaton, D. E., Bombardier, C., Guillemin, F., \& Ferraz, M. B. (2000). Guidelines for the process of cross-cultural adaptation of self-report measures. Spine, 25(24), 3186-3191. doi:10.1097/00007632200012150-00014

Burlá, C., \& Py, L. (2014). Palliative care: Science and protection at the end of life. Cadernos Saúde Pública, 30(6), 1139-1141. doi:10.1590/0102-311X- 
PE020614

Gjersing, L., Caplehorn, J. R., \& Clausen, T. (2010). Cross-cultural adaptation of research instruments: Language, setting, time and statistical considerations. BMC Medical Research Methodology, 10(13), 1-10. doi:10.1186/1471-2288-10-13

Henderson, A., Rowe, J., Watson, K., \& Hitchen-Holmes, D. (2016). Graduating nurses' self-efficacy in palliative care practice: An exploratory study. Nurse Education Today, 39, 141-146. doi: 10.1016/j.nedt.2016.01.005

Iaochite, R. T., Costa Filho, R. A., Matos, M. M., \& Sachimbombo, K. M. (2016). Autoeficácia no campo educacional: Revisão das publicações em periódicos brasileiros. Psicologia Escolar e Educacional, 20(1), 45-54. doi:10.1590/2175-353920150201922

Kassa, H., Murugan, R., Zewdu, F., Hailu, M., \& Woldeyohannes, D. (2014). Assessment of knowledge, attitude and practice and associated factors towards palliative care among nurses working in selected hospitals, Addis Ababa, Ethiopia. BMC Palliative Care, 13(1), 6. doi:10.1186/1472-684x-13-6

Mutto, E. M., Cantoni, M. N., Rabhansl, M. M., \& Villar, M. J. (2012). A perspective of end-of-life care education in undergraduate medical and nursing students in Buenos Aires, Argentina. Journal of Palliative Medicine, 15(1), 93-98. doi:10.1089/ jpm.2011.0238

Nakazawa, Y., Miyashita, M., Morita, T., Umeda, M., Oyagi, Y., \& Ogasawara, T. (2009). The palliative care knowledge test: Reliability and validity of an instrument to measure palliative care knowledge among health professionals. Palliative Medicine, 23(8), 754-766. doi:10.1177/0269216309106871

Pfister, D., Markett, S., Muller, M., Muller, S., Grutzner, F., Rolke, R., \& Radbruch, L. (2013). German nursing home professionals' knowledge and specific self-efficacy related to palliative care. Journal of Palliative Medicine, 16(7), 794-798. doi:10.1089/jpm.2012.0586

Pfister, D., Muller, M., Muller, S., Kern, M., Rolke, R., \& Radbruch, L. (2011). Validation of the Bonn test for knowledge in palliative care (BPW). Schmerz,
25(6), 643-653. doi:10.1007/s00482-011-1111-7

Prem, V., Karvannan, H., Kumar, S. P., Karthikbabu, S., Syed, N., Sisodia, V., \& Jaykumar, S. (2012). Study of nurses' knowledge about palliative care: A quantitative cross-sectional survey. Indian Journal Palliative Care, 18(2), 122-127. doi:10.4103/09731075.100832

Prince, M. J., Wu, F., Guo, Y., Gutierrez Robledo, L. M., O’Donnell, M., Sullivan, R., \& Yusuf, S. (2015). The burden of disease in older people and implications for health policy and practice. The Lancet, 385(9967), 549-562. doi:10.1016/s01406736(14)61347-7

Ross, M. M., McDonald, B., \& McGuinness, J. (1996). The palliative care quiz for nursing (PCQN): The development of an instrument to measure nurses' knowledge of palliative care. Journal of Advanced Nursing, 23(1), 126-137. doi:10.1111/j.1365-2648.1996.tb03106.x

Seow, H., Brazil, K., Sussman, J., Pereira, J., Marshall, D., Austin, P. C., . . . Barbera, L. (2014). Impact of community based, specialist palliative care teams on hospitalisations and emergency department visits late in life and hospital deaths: A pooled analysis. BMJ, 348, g3496. doi:10.1136/bmj.g3496

Tripodoro, V. A., Rynkiewicz, M. C., Llanos, V., Padova, S., De Lellis, S., \& De Simone, G. (2016). Palliative care needs in advanced chronic illness. Medicina, 76(3), 139-147. Retrieved from http://www.medicinabuenosaires.com/PMID/27295702.pdf

van Riet Paap, J., Vernooij-Dassen, M., Brouwer, F., Meiland, F., Iliffe, S., Davies, N., .... Engels, Y. (2014). Improving the organization of palliative care: Identification of barriers and facilitators in five european countries. Implementation Science, 9, 130. doi:10.1186/s13012-014-0130-z

Visser, C., Hadley, G., \& Wee, B. (2015). Reality of evidence-based practice in palliative care. Cancer Biology \& Medicine, 12(3), 193-200. doi:10.7497/j. issn.2095-3941.2015.0041

World Health Organization. (2015). WHO media centre, fact sheet $n^{\circ} 402$. Retrieved from http://www. who.int/mediacentre/factsheets/fs402/en/ 
